\title{
A review of drugs that contribute to bleeding risk in general dental practice
}

Leanne Teoh, ${ }^{1}$ Geraldine Moses, ${ }^{2}$ Michael McCullough ${ }^{1}$

${ }^{1}$ Melbourne Dental School, The University of Melbourne, Carlton, Victoria, Australia

${ }^{2}$ School of Pharmacy, University of Queensland, Woolloongabba, Queensland, Australia

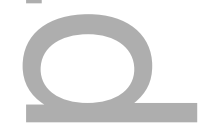

\section{Acknowledgements}

This research was supported by the Australian Government Research Training Program

Scholarship (no. 241616)

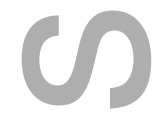

Address for correspondence:

Dr Leanne Teoh

Melbourne Dental School

The University of Melbourne

720 Swanston Street

Carlton VIC 3010

Australia

Email: leanne.teoh@unimelb.edu.au

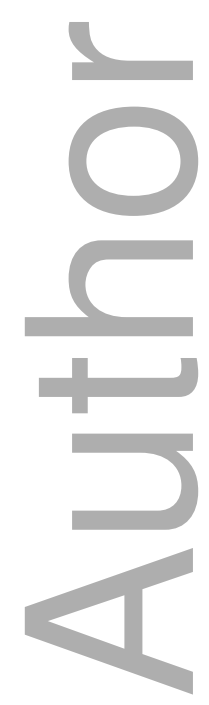

This is the author manuscript accepted for publication and has undergone full peer review but has not been through the copyediting, typesetting, pagination and proofreading process, which may lead to differences between this version and the Version of Record. Please cite this article as doi: $10.1111 /$ ADJ.12751

This article is protected by copyright. All rights reserved 


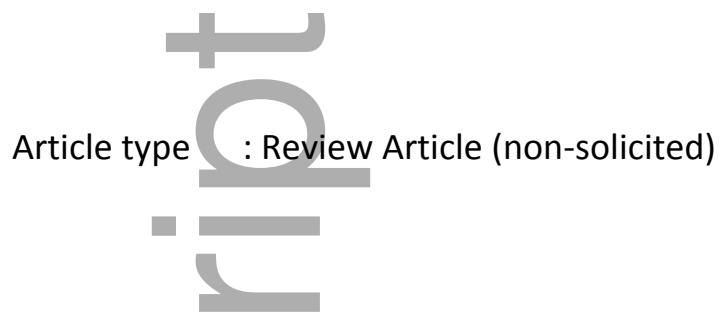

A review of drugs that contribute to bleeding risk in general dental practice

Leanne Teoh, ${ }^{1}$ Geraldine Moses, ${ }^{2}$ Michael McCullough ${ }^{1}$

${ }^{1}$ Melbourne Dental School, The University of Melbourne, Carlton, Victoria, Australia

${ }^{2}$ School of Pharmacy, University of Queensland, Woolloongabba, Queensland, Australia

\title{
Address for correspondence:
}

Dr Leanne Teoh

Melbourne Dental School

The University of Melbourne

720 Swanston Street

Carlton VIC 3010

Australia

Email: leanne.teoh@unimelb.edu.au

\begin{abstract}
The risk of post-operative bleeding is a daily concern for many general dental practitioners. A thorough medical and medication history must be taken in order to consider all risk factors, particularly drugs, that contribute to bleeding risk. While the risk from drugs such as aspirin, warfarin and clopidogrel are well-known, the extent to which new anti-platelet agents and direct oral anticoagulants affect bleeding risk is less well understood. In addition, there are drugs other than anti-thrombotics, such as antidepressants and complementary medicines that also impair haemostasis. The aim of this paper is to provide dentists with an updated
\end{abstract}


overview of the drugs commonly encountered in general dental practice that can contribute to a patient's post-operative bleeding risk.

\section{Introduction}

Risk of post-operative bleeding is a daily concern for most general dental practitioners. Guidelines now recommend that bleeding risk is assessed from three main sources: patient, procedure- and drug-related factors. ${ }^{1-3}$ Patient factors include age, medical conditions, oral health, liver impairment and inherited bleeding disorders. Procedure factors include the degree of tissue trauma involved and number of teeth extracted. Regarding drugs, dentists must consider all the drugs a patient is taking that may exaggerate bleeding risk, not just the well-known anti-thrombotic drugs such as aspirin, heparin, clopidogrel and warfarin. There are now a wide range of drugs from varied classes that can contribute to post-operative bleeding. These include the new anti-platelet drugs and the new direct-acting oral anticoagulant drugs (DOACs) that are increasingly popular for management of thrombotic risk throughout medical and surgical specialities. Other drugs such as antidepressants, nonsteroidal anti-inflammatory drugs (NSAIDs), herbal and complementary medicines also add to bleeding risk both directly and indirectly through drug interactions.

The aim of this paper is to review all drugs that can contribute to a patient's potential for post-operative bleeding in the dental setting.

\section{Physiology of haemostasis}

Haemostasis is defined as the mechanism by which blood loss from a damaged blood vessel is arrested. ${ }^{4,5}$ The process of haemostasis involves constriction of the blood vessel and activation of the coagulation process, formation of a platelet plug, followed by formation of a fibrin clot with aggregated platelets. ${ }^{5}$ The cell-based model of coagulation describes these steps as initiation, amplification and propagation that lead to the conversion of fluid blood to a solid gel or clot.

Initial damage to the blood vessel releases chemical factors that trigger vascular spasm and vasoconstriction to reduce blood loss. ${ }^{6}$ The initiation phase of the coagulation process is triggered by binding of tissue factor (TF) overexpressed on subendothelial cells to Factor VII. A series of enzymatic reactions subsequently leads to the activation of Factor Xa, which 
combines with Factor Va to convert prothrombin to thrombin (Factor II to Factor IIa respectively). ${ }^{7}$

In the next phase of amplification, the small amount of thrombin generated from initiation phase results in the development of a positive feedback loop to induce a large amount of thrombin derived from both platelets and other proteins. ${ }^{6,7}$ Thrombin further acts on other coagulation proteins resulting in the production of coagulation factors Va, VIIIa, IXa and Xa that adhere to the surface of platelets. ${ }^{6}$ Propagation is the final phase, activated platelets and activated factors convert large amounts of prothrombin to thrombin on the platelet surface. ${ }^{6}$ Fibrinogen is then converted to fibrin via thrombin. Fibrin strands are incorporated to stabilised the platelet plug, forming the blood clot. ${ }^{6}$ The coagulation process is shown in Figure 1.

\section{Platelet plug formation}

Platelets adhere to the exposed collagen of the thrombogenic endothelium and are activated to secrete both alpha and dense granules, the contents of which include ADP and serotonin. ${ }^{4}$ The biosynthesis of mediators such as thromboxane A2 (TXA2) and platelet activating factor also occurs in the process of platelet aggregation to form the primary platelet plug. ${ }^{4}$ However, it is the binding to the P2Y12 receptor on the surface of platelets by ADP that are predominately responsible for prolonged platelet activation. ${ }^{8}$

\section{Anti-platelets}

\section{Aspirin and Dipyridamole}

Aspirin is most commonly used in combination with other anti-platelet agents for prevention of acute coronary syndromes, ischaemic stroke and transient ischaemic attack (TIA). ${ }^{9}$ It is also used in a variety of other settings to prevent blood clot formation such as in the prevention of pre-eclampsia in moderate-high risk pregnant women. ${ }^{9}$ Aspirin functions by irreversibly acetylating and inactivating the enzyme cyclooxygenase on the platelet surface that reduces the synthesis of the TXA2 and permanently impairs platelet aggregation for the lifetime of that platelet. ${ }^{10}$ Recently published clinical trials (ASPREE, ARRIVE) ${ }^{11-14}$ have shown that there insufficient benefit from aspirin in primary prevention of stroke and MI to 
outweigh the bleeding risk. Low daily doses of 75-150mg are mostly recommended for secondary prevention of acute cardiovascular adverse events. ${ }^{15}$ As with all irreversible inhibitors of platelet function, recovery of normal platelet function occurs at a rate depending on platelet turnover and this is approximately 5-7 days after drug cessation. ${ }^{16}$

Dipyridamole is indicated for the secondary prevention of ischaemic stroke. This drug's antithrombotic action is postulated to be due to inhibition of adenosine on platelets and erythrocytes, as well as inhibition of phosphodiesterase. ${ }^{10,17}$ It has a greater antithrombotic effect when administered simultaneously with aspirin, creating synergistic platelet inhibition ${ }^{17}$ Nonetheless, when compared with aspirin, the antiplatelet activity of dipyridamole alone is less pronounced, and its effect on phosphodiesterase inhibition is reversible, so resolves about 24 hours after the drug is ceased.

\section{$\underline{\mathrm{P} 2 \mathrm{Y} 12 \text { inhibitors }}$}

Inhibition of the P2Y12 receptor on platelets prevents the binding of ADP that subsequently prevents activation of the GPIIb/IIIa complex impairing platelet aggregation. ${ }^{8}$ Drugs that inhibit the P2Y12 receptor can do so either reversibly or irreversibly. Thienopyridines, which include clopidogrel and prasugrel, are both pro-drugs and after undergoing liver metabolism to their active metabolites irreversibly inhibit the P2Y12 receptor. Ticagrelor is a directacting $\mathrm{P} 2 \mathrm{Y} 12$ receptor inhibitor but its action is to change receptor morphology in a reversible manner. ${ }^{8}$

Clopidogrel is indicated for prevention of myocardial infarction and stroke treatment of acute coronary syndrome in combination with aspirin. ${ }^{9}$ Platelet inhibition by clopidogrel is dose-dependent, but not proportional to the increase in dose, with average inhibition of ADPinduced platelet aggregation (IPA) between 40-60\% with a standard dose of clopidogrel $75 \mathrm{mg}$ daily at steady state. ${ }^{8,16}$ A systematic review found that there is a delayed onset and variability in platelet inhibition with clopidogrel, with $15-40 \%$ of individuals exhibiting a poor response, postulated to be due to pharmacogenomic variability in the enzymes (CYP2C19, CYP2C9 and CYP2B6) that metabolise clopidogrel to its active metabolite. ${ }^{8}$ This genetic variability in response does not affect prasugrel or ticagrelor. 
Prasugrel is used in combination with aspirin to prevent acute coronary syndrome in patients who have a post-coronary stent placement. ${ }^{9}$ Prasugrel has a faster onset of action and greater antiplatelet effects compared with clopidogrel. ${ }^{18}$ Maintenance doses of prasugrel of $10 \mathrm{mg}$ daily produces an average of 50\% platelet inhibition, with maximum levels of IPA of $65-75 \%$ being produced at daily doses greater than $20-30 \mathrm{mg} .{ }^{8}$ Use of prasugrel in combination with aspirin increases the bleeding risk significantly beyond that expected from prasugrel alone.

Ticagrelor is also indicated for prevention of acute coronary syndrome in combination with aspirin. ${ }^{9}$ A rapid onset of action is achieved around 30 minutes after a loading dose is given, with the high IPA effect of around 87-89\% achieved after 2-8 hours and maintained at steady state with maintenance therapy. ${ }^{19}$ A double-blinded comparison study found that in doses of $100 \mathrm{mg}$ twice daily or higher resulted in approximately $90 \%$ of platelet inhibition in patients with stable atherosclerosis. ${ }^{20,21}$ The landmark PLATO (Platelet Inhibition and Platelet Outcomes) study, a multicentre double-blinded randomised clinical trial conducted by Wallentin and colleagues, found that compared with clopidogrel, ticagrelor significantly reduced the death rate from vascular causes such as myocardial infarction and stroke, without an increase in the rate of overall major bleeding. ${ }^{21}$ A summary of all the anti-platelets is shown in Table 1.

\section{Anti-coagulants}

\section{$\underline{\text { Heparin and low molecular weight heparin }}$}

Heparin is indicated for the prophylaxis and treatment of thromboembolic disorders, to prevent thrombotic complications of various surgeries, and as an anticoagulant in blood transfusions. Heparin itself is a naturally occurring family of sulphated glycosaminoglycans with a range of molecular weights. ${ }^{4}$ Heparin's anti-thrombotic mechanism of action occurs by enhancing the effect of antithrombin III, an endogenous anticoagulant ${ }^{4,22}$ that blocks the effects of Factor Xa, thrombin and other serine proteases. ${ }^{4}$ The anticoagulant effect of heparins can be monitored by measuring activated partial thromboplastin time (aPTT) and the dose individualised. An advantage of using heparin is its rapid onset of action and ability to reverse its effects with the antidote protamine, which is why heparins are used as "bridging" for patients who require anticoagulation throughout surgery. However, two disadvantages are its poor oral bioavailability such that it must be administered parenterally, and the risk of heparin-induced thrombocytopenia. ${ }^{6}$ 
Low molecular weight (LMW) heparins are fragments of unfractionated heparin that bind to anti-thrombin III but predominately inhibit Factor Xa only. ${ }^{4}$ LMW heparins are increasingly used instead of unfractionated heparin due to their reduced risk of side effects and decreased need for monitoring. ${ }^{4}$ A standard dose of LMW heparin can be calculated by body weight, however dose adjustment is required for obese patients and those with declining renal function. Patients can self-administer the LMWH subcutaneously from pre-filled syringes at home.

Heparins are usually the anticoagulant of choice peri-operatively due to their rapid onset and offset, and reversibility with protamine. However, low prophylactic doses must be used to reduce risk of bleeding during surgery, which may persist for up to 12 hours after IV heparin administration and up to 36 hours after LMWH administration is ceased. ${ }^{9}$

\section{Warfarin}

Warfarin is a well-known anticoagulant but its use in the community is declining due to the availability of newer agents. Warfarin works by inhibiting the enzyme vitamin K epoxide reductase (VKORC) in the liver that leads to reduced synthesis of vitamin K-dependent clotting factors II, VII, IX and X. Warfarin also inhibits proteins $\mathrm{C}$ and $\mathrm{S}$ that are involved in the fibrinolytic system and also require vitamin $\mathrm{K}$ for their function. ${ }^{23}$ Warfarin is currently indicated for the prevention and treatment of venous thromboembolism in atrial fibrillation and prevention of coronary syndromes for people with increased risk factors such as prosthetic heart valves. ${ }^{9}$

While peak plasma concentrations of warfarin are achieved after one hour, reduced hepatic synthesis of clotting factors takes 2-3 days to reach observable clinical effects. ${ }^{4}$ In addition, the clinical effect of a single dose can last for 4-5 days as it is dependent on regeneration of unaffected clotting factors.

It is well known that warfarin is vulnerable to many drug interactions including that due to variability in the patient's ingestion of dietary or supplemented vitamin K. This is further complicated by the fact that warfarin products contain a racemic mixture of its two isomers, R- and S-warfarin, which are metabolised differently from each other and therefore interact with other drugs differently. R-warfarin is a substrate for the cytochrome P450 enzymes CYP1A2, CYP3A4, CYP2C19, whereas S-warfarin, the more potent isomer, is a substrate for CYP2C9, and so the outcome of drug interactions can be very difficult to predict. ${ }^{9}$ Genetic 
status also contributed to variability in warfarin response due to polymorphism of the enzyme CYP2C9 and VKORC.

Due to the significant variability in absorption and metabolism between patients, serum levels and pharmacological effects of warfarin can vary greatly so its anticoagulant effect needs to be monitored and the dose of warfarin individualised. Warfarin's anticoagulant effect is monitored by measuring prothrombin time, which is standardised to the International Normalised Ratio (INR). For prevention of serious thromboembolism INR is usually maintained between 2.0 and 4.0 although this varies with the condition being treated and is individualised to each patient. ${ }^{23}$

\section{$\underline{\text { Direct-acting oral anticoagulants }}$}

The many limitations of warfarin inspired the development of the direct-acting oral anticoagulants (DOACs), of which three are currently approved for use in Australia: Dabigatran, Rivaroxaban and Apixaban. Use of these medicines has superseded warfarin, with all three in the top 100 drugs dispensed on the Pharmaceutical Benefits Scheme in 2018. ${ }^{24}$ DOACs have more predictable pharmacokinetics and dose response than warfarin so their degree of anticoagulation does not require regular monitoring, ${ }^{25}$ which in turn enhances patient adherence. There are two classes of DOACs, direct thrombin inhibitors (dabigatran) and Factor Xa inhibitors (apixaban and rivaroxaban). The key advantage of DOACs over warfarin is their rapid onset and offset of action. Their direct impairment of thrombus formation in the blood stream results in them being effective within hours of the first dose and wear off within a day of cessation.

\section{Dabigatran}

Dabigatran was the first DOAC to be marketed and acts as a reversible inhibitor of both free and fibrin-bound thrombin thus preventing the conversion of fibrinogen to fibrin and clot formation. ${ }^{26}$ It is indicated for the prevention and treatment of venous thromboembolism (VTE) following hip or knee replacement, as well as prevention of stroke in non-valvular atrial fibrillation. ${ }^{27}$ Dabigatran has poor oral bioavailability as it is presented as a pro-drug dabigatran etexilate, which requires conversion to the active form by esterase-catalysis hydrolysis in the plasma and liver, and oral absorption is dependent on low gastric $\mathrm{pH}$ and transport by p-glycoprotein in the gut wall. Peak plasma concentrations are obtained within 
$0.5-2$ hours and the half-life is $12-17$ hours. ${ }^{26,27}$ Dabigatran is predominately renally excreted unchanged (80\%), so doses must be reduced in mild-moderate renal impairment and the drug is contraindicated in severe renal impairment (creatinine clearance of $<30 \mathrm{ml} / \mathrm{min}$ ). ${ }^{27}$ Risk of gastrointestinal bleeding with dabigatran have been found to be greater than for warfarin, so warfarin is the preferred drug in patients at risk of gastrointestinal ulceration. ${ }^{27}$ No blood test has yet been validated for monitoring dabigatran's anticoagulant effect, however thrombin time and aPTT may be used in emergency settings. ${ }^{27}$

The antidote to dabigatran, idaricuzumab (Praxbind) is a humanised monoclonal antibody that binds to dabigatran and its metabolites to form a stable, inactive complex. It is administered intravenously in emergency settings for rapid reversal (within 5 minutes) of dabigatran anticoagulant effects for emergency surgery, urgent procedures or for life threatening/uncontrolled bleeding. ${ }^{9}$

\section{Rivaroxaban}

Rivaroxaban is indicated for the prevention of VTE following elective hip or knee replacement, prevention and treatment of VTE and for the prevention of stroke in patients with non-valvular atrial fibrillation. ${ }^{9}$ Being a selective, direct Factor Xa inhibitor, rivaroxaban prevents the conversion of prothrombin to thrombin, thus inhibiting thrombus formation. Factor Xa inhibitors are rapidly acting anticoagulants since they act at the amplification site of the coagulation process. ${ }^{7}$ While the manufacturers state that there is no need for monitoring of coagulation parameters, anti-Factor Xa assays can be used to measure the anticoagulant effect in emergency situations. ${ }^{28,29}$

Rivaroxaban has high oral bioavailability (80-100\%) with time to peak plasma concentration achieved within 2-4 hours. ${ }^{29}$ However there is some degree of variability in absorption and distribution as rivaroxaban is a substrate for p-glycoprotein in the gut wall, is highly protein bound (92-95\%), and approximately two thirds undergoes metabolism by CYP3A4 enzymes and others, leading to many drug interactions and altered drug concentrations. ${ }^{29}$ The remaining one third is excreted unchanged in the urine. Elimination half-lives of rivaroxaban therefore vary, with around 5-9 hours in young individuals and 11-13 hours in older people. ${ }^{28,}$ 29 
While not marketed for use in Australia as yet, the antidote for rivaroxaban, Andexanet alfa, has been approved for use in the US by the FDA to reverse the anticoagulant effects of Factor $\mathrm{Xa}$ inhibitors in life-threatening bleeding or emergency surgery. ${ }^{28}$

Apixaban

Apixaban was the third DOAC to be approved worldwide, and is also a direct Factor Xa inhibitor with the same approved indications as rivaroxaban. ${ }^{9}$ In clinical trials using DOACs for prevention of stroke in atrial fibrillation, apixaban was found to be the most effective. However, its twice daily dosing makes it less popular than rivaroxaban, which is prescribed once daily. ${ }^{30}$ Apixaban's oral bioavailability is around 50\%, with p-glycoprotein transport in the gut wall influencing absorption and peak plasma concentrations appearing between 3-4 hours after oral administration. ${ }^{28,30}$ The elimination half-life is around 12 hours. Renal clearance is only around $27 \%$ with the remainder undergoing liver metabolism and biliary excretion. ${ }^{30}$ Apixaban is predominantly metabolised by CYP3A4/5 enzymes in the liver, ${ }^{30}$ making it subject to many drug interactions.

While apixaban has been demonstrated to prolong clotting tests such as prothrombin time, INR and aPTT, the changes observed show high variability and so are not recommended to measure the anticoagulant effects. ${ }^{28,30}$ A summary of all the anticoagulants is shown in Table 2.

\section{Bleeding risk of antiplatelets and anticoagulants in dentistry}

Dentists will encounter an increasing number of patients taking new antiplatelet agents and DOACs due to their key roles in managing prothrombotic conditions commonly encountered in our aging population. Dentists should understand the clinical reasoning behind the use of these medications, so the bleeding risk they create can be weighed against the thrombotic risk should these medications be stopped. ${ }^{31,32}$ In most cases the drugs should not be stopped, as such cessation would put the patient at too high a risk of ischaemic events and conventional haemostatic measures are generally all that is required for simple dental procedures such as a single tooth extraction. ${ }^{31,32}$ However, if more extensive procedures need to be undertaken, assessment between the risk of not having surgery versus the risk of coronary events should be discussed in consultation with the prescribing physician. If the patient's anti-thrombotic 
regimen needs to be altered, it should only be done under supervision, consultation and prescription of the prescribing medical practitioner. ${ }^{32}$

Several studies have emerged about the use of the new anti-thrombotics in dental practice. An extensive review of the literature showed that DOACs carry a relatively low post-operative bleeding risk. ${ }^{25}$ They found that when dental procedures were undertaken without interruption of the medication regimen, the bleeding could be managed with conventional haemostatic measures. However, cases should be individualised and patients who have other risk factors that may potentiate bleeding such as a more complex or invasive procedures or other clinical characteristics, consultation with the prescribing physician was recommended. ${ }^{25}$ A 2018 systematic review and meta-analyses by Bensi et al regarding postoperative bleeding risk with DOACs after oral surgery showed that patients taking DOACs had a three-fold increased risk of bleeding compared with non-users, with rivaroxaban appearing to have a higher risk than dabigatran. ${ }^{33}$ Furthermore, a prospective observational study of 51 patients taking either DOACs or a vitamin K antagonist (INR between 2.0 and 3.0) found that rates of post-operative bleeding were not significantly different between the two groups and no bleeding episodes required hospitalisation. They concluded that dental extractions could be undertaken without stopping the antithrombotic regimen. ${ }^{34}$ Several studies have also investigated the effect of antiplatelets on bleeding risk in dental practice. A retrospective study of the bleeding frequency in patients taking ticagrelor, aspirin, clopidogrel and the combination of aspirin with clopidogrel found that drug therapy did not need to be stopped for tooth extractions and again that local measures are adequate to control post-operative bleeding. ${ }^{35}$ Underscoring the findings of these studies, an observational, multi-centre prospective cohort study found that dental extractions could proceed safely using local measures for haemostasis without stopping therapy. Patients included were taking aspirin and another antiplatelet agent, either clopidogrel, ticlopidine, prasugrel or ticagrelor. ${ }^{36}$ Lastly, an evidence summary of the management of patients taking prasugrel and ticagrelor concluded that while cases of gingival bleeding had been documented, no evidence of troublesome bleeding had been reported after invasive dental procedures and local measures were sufficient to manage post-operative bleeding. ${ }^{18}$

\section{Non-steroidal anti-inflammatory drugs}


Non-selective non-steroidal anti-inflammatory drugs (NSAIDs) including diclofenac, ibuprofen, indomethacin, ketoprofen, ketorolac, mefenamic acid, naproxen, piroxicam and sulindac, are taken either regularly or intermittently for management of pain due to inflammatory arthropathies, such as rheumatoid arthritis, osteoarthritis and gout. ${ }^{9}$ Like aspirin, non-selective NSAIDs can inhibit cyclo-oxygenase (COX) on platelets and increase the risk of bleeding. But unlike aspirin, this effect is reversible and short-lived with NSAIDs lasting only 4-6 hours. Therefore, the risk of peri- and post-operative bleeding with NSAIDS is less significant than it is with aspirin, as it does not last for the lifetime of the platelet.

In general, only regular, long-term use of non-selective NSAIDs is associated with an increased risk of post-operative bleeding as their reversible inhibition of COX 1 suppresses the production of TXA2 which subsequently results in anti-platelet effects. However, this does not apply to short term, low dose use of NSAIDs as the effect has been shown not to be clinically significant. This is why short-term use of short-acting NSAIDs such as ibuprofen for acute postoperative pain is not associated with increased risk of bleeding. ${ }^{37}$

\section{Antidepressants - Selective serotonin re-uptake inhibitors and venlafaxine}

Selective serotonin re-uptake inhibitors (SSRIs) and venlafaxine (a serotonin and noradrenaline re-uptake inhibitor, SNRI) are commonly prescribed drugs, with citalopram, escitalopram, fluoxetine, paroxetine, sertraline and venlafaxine being in the top 100 dispensed drugs on the Australian Pharmaceutical Benefits Scheme in $2018 .{ }^{24}$ In addition to depression, these drugs are used for a range of anxiety disorders and are increasingly used for off-label indications such as premenstrual dysphoric disorder, post-traumatic stress disorder and bulimia nervosa.

There is growing literature that associates serotonergic antidepressants with an increased risk of bleeding. ${ }^{38,39}$ SSRIs have been associated with oral adverse effects relating to bleeding, including prolonged bleeding time, petechiae, ecchymosis, bruising and gingival bleeding. ${ }^{38}$ The proposed mechanism by which this occurs is by the inhibition of serotonin reuptake into platelets. Serotonin, in conjunction with other factors including ADP and prothrombin, potentiate platelet aggregation. Mature platelets rely on the reuptake of plasma serotonin as they cannot produce their own serotonin. ${ }^{38,39}$ However, SSRIs block the serotonin receptor, subsequently causing a decrease in platelet intracellular concentration and therefore impairing platelet aggregation. ${ }^{38,39}$ 
Several population-based studies have associated the use of SSRIs with increased risk of gastrointestinal bleeding, with fluoxetine, paroxetine and sertraline being the most frequently involved. ${ }^{40,41}$ A case control study demonstrated that antidepressants with a relevant blockade action on the serotonin reuptake mechanism would increase gastro-intestinal bleeding, with venlafaxine being the only SNRI with enough evidence to show a significantly increased risk compared to matched controls. ${ }^{42,43}$ Various studies have aimed to quantify the degree of increased bleeding risk, with a number of systemic reviews and meta-analyses, expert opinion and a population-based cohort study estimating the increased risk of gastrointestinal bleeding of a subject taking an SSRI to be between 1.55 to 3.6 times compared to non-SSRI users. ${ }^{40,44-46}$ It is established that the risk of bleeding is increased even more with concurrent SSRI and NSAID use, with the risk estimated to be between 4.25-12.2 times greater. ${ }^{40,44-46}$

In addition to having an anti-thrombotic effect, serotonin has a vasoconstrictive effect on arteries in the central nervous system. A systematic review and meta-analysis showed that SSRIs are associated with an increased risk of both ischaemic and haemorrhagic (intracerebral) stroke. ${ }^{39}$ A population-based study also concluded that SNRIs were associated with a higher risk of stroke compared to SSRIs, with the SNRIs included in the study were venlafaxine, desvenlafaxine and duloxetine. ${ }^{47}$ A meta-analysis of high-level observational studies concluded that the increased risk of bleeding was $36 \%$ with SSRI use, with intracranial bleeding having a similar proportional risk to gastrointestinal bleeding. ${ }^{48} \mathrm{~A}$ retrospective cohort study showed that the frequency of oral bleeding complications after invasive dental procedures is low to negligible in patients taking SSRIs. ${ }^{38}$ Dentists should be aware that while SSRIs are unlikely to carry a clinical bleeding risk in isolation, they may elevate a patient's bleeding risk in combination with other anti-thrombotics. ${ }^{3}$ If an antidepressant needed to be stopped it should not be done so without medical supervision, as most require gradual dose tapering over two to four weeks. Table 3 shows the antidepressants associated with increased bleeding risk.

\section{Complementary medicines}

Complementary medicines (CM) are defined as vitamins, minerals, herbal and nutritional supplements, homeopathic and some aromatherapy products (where medicinal claims are made), ${ }^{49}$ which due to their pharmacological effects or via drug interactions can significantly 
contribute to perioperative bleeding risk. This is important as studies show CMs are utilised by around two thirds of the Australian population. ${ }^{50}$ A systematic review showed that, most frequent users are middle-aged females with higher education, ${ }^{51}$ however they are also commonly used by children, the elderly and people with complex medical conditions. CM use for chronic disease such as cancer, musculoskeletal diseases (rheumatoid arthritis, osteoporosis, osteoarthritis and gout), inflammatory bowel disease, cardiovascular diseases, mental health and diabetes are also common. ${ }^{51}$ While the safety of CMs in Australia is regulated to some extent by the Therapeutic Goods Administration (TGA), most CM products do not carry warning about adverse effects such as increased bleeding risk. In addition, many CM products are obtained online or via channels that bypass conventional health care practice. ${ }^{51}$ Patients often do not report their CM use to health professionals and are frequently unaware of their potential drug-drug or drug-procedure interactions. ${ }^{52,53}$ Yet many CMs may add to bleeding risk by increasing serum concentrations of an antithrombotic, further increasing its bleeding risk.

Several herbal products, such as ginkgo biloba and fish oil, have been identified to have antithrombotic properties and have been reported to increase patient bleeding risk. Common herbal supplements that are associated with an increased bleeding risk in the dental setting was reviewed in detail by Abebe,${ }^{52}$ but will be summarised here. The following is a brief discussion of some of the commonly used herbal products which have reports of effects of either blood clotting, increased bleeding during surgery or interactions with conventional anti-thrombotic medicines.

\section{Herbal products with anti-thrombotic properties}

Dong quai is a traditional Chinese medicine used for treating migraines and gynaecological problems. ${ }^{52,54}$ Components of dong quai include coumarin derivatives, which have been shown to prolong prothrombin time, increase bleeding and potentiate the effect of warfarin. ${ }^{52}$, ${ }^{55,56}$ In vivo and in vitro studies also show that another component of dong quai, ferulic acid has antiplatelet activity. ${ }^{52,57}$

Fish oil is used for hypertriglyceridemia, ${ }^{9}$ although high doses (greater than $3 \mathrm{~g} / \mathrm{daily}$ ) have an antiplatelet effect, and are associated with reduction of TXA2, decreased platelet aggregation and increased bleeding time. ${ }^{58}$

Evening primrose oil is a supplement used for indications including arthritis, multiple sclerosis, premenstrual symptoms. ${ }^{52}$ Constituents of evening primrose include fatty acids, 
such as omega-6 fatty acid, gamma-linoleic acid, and has been reported to reduce thromboxane production and therefore platelet aggregation in hyperlipidemic male patients. ${ }^{52}$ Animal studies have shown that the seed oil of the herb has anti-thrombotic effects. ${ }^{59}$

Garlic is another well-known supplement used for cardiovascular benefits including hypertension, hyperlipidaemia, diabetes, and other conditions. ${ }^{52,60}$ Various human studies have demonstrated that garlic has an anti-thrombotic effect, ${ }^{61}$ and it has also been associated with increasing the anti-thrombotic properties of aspirin, NSAIDs and warfarin. ${ }^{52,54}$ An active compound in garlic, allicin, has been shown to interfere the production and/or release of chemical mediators involved in the clotting process, such as platelet activating factor (PAF), adenosine, ADP and thromboxanes, as well as inhibition of cyclooxygenase and fibrinogen receptors which is responsible for the its anti-thrombotic properties. ${ }^{52,62}$

Ginger is frequently used for various medical reasons, including nausea, vomiting, arthritis, arthritis and cardiovascular conditions. ${ }^{52,63}$ One case report has demonstrated an association of increased bleeding with warfarin. ${ }^{64}$ The constituents of ginger, zingiberene, bisabolene, shogaol and gingerols have been reported to inhibit TXA2 synthesis and therefore have antiplatelet effects. 65

Gingko biloba is used for a range of conditions such as circulatory disorders, dementia, vertigo, tinnitus and to improve memory and cognitive function. ${ }^{52,58,63}$ In vitro studies have shown that active ingredients, ginkgolides confer anti-platelet properties by inhibiting platelet aggregation by inhibiting PAF formation. ${ }^{58,66}$ This can occur after being used for a minimum of 2-3 weeks. Several case reports have been published of spontaneous bleeding, and excessive postoperative bleeding following dental surgery, total hip arthroplasty and retrobulbar haemorrhage during cataract surgery. ${ }^{58,66,67}$

Ginseng (American, or Panax quinquefolius) is often used to enhance the immune function, increase energy and alertness, cognitive disorders and vascular diseases. ${ }^{52,63}$ Active constituents in ginseng, ginsenosides, have been shown to inhibit TXA2 formation and platelet aggregation. ${ }^{52,68}$ Several case studies have shown the association of ginseng use with increased bleeding in patients. ${ }^{52,69}$ Ginseng, garlic, ginkgo and ginger are all not recommended to be taken as supplements concomitantly with warfarin due to the increased risk of bleeding. ${ }^{70}$

Glucosamine is commonly used for osteoarthritis, either alone or in combination with chondroitin. Many case reports exist of an interaction between glucosamine, chondroitin and 
warfarin, which has resulted in a significantly increased INR, or increased bruising and bleeding events. ${ }^{58}$ Several case reports also associate glucosamine alone with an increased INR with patients who are taking warfarin. ${ }^{58} \mathrm{~A}$ human study conducted to determine the effects of glucosamine on platelet function concluded that glucosamine and celadrin is associated with inhibition of platelet aggregation by inhibition of the ADP receptor P2Y $1 .{ }^{71}$ It is recommended that glucosamine should be stopped prior to invasive procedures if possible until more is determined about the anti-thrombotic effects. ${ }^{58}$ The cessation of glucosamine short-term prior to invasive procedures is unlikely to significantly reduce its effect on osteoarthritis pain due to its a slow onset of action. ${ }^{9,58}$

Turmeric (curcumin) has recently gained popularity as an anti-inflammatory to treat inflammatory, pain, arthritis and skin infections. ${ }^{52}$ Identified constituents are the volatile oils, zingiberene and turmerone, and curcuminoids, the latter of which is responsible for the antiinflammatory and anti-platelet effects. ${ }^{72}$ Inhibition of TXA2 synthesis and arachidonic acid metabolism has been demonstrated with in vitro experiments. ${ }^{72}$ An in vitro study ${ }^{73}$ and animal studies ${ }^{74}$ also demonstrated that curcumin was a relatively strong inhibitor of platelet aggregation. Additionally, curcuminoids inhibit several enzymes including CYP 3A4, 1A2, 2D6 and also may inhibit p-glycoprotein transport, thereby having many drug interactions including all of the oral anticoagulants. ${ }^{75}$

A summary of these CMs are showed in Table 4. While many other herbal supplements may contribute to an increased bleeding risk, most would not be identified or reported as regulation and testing of $\mathrm{CM}$ is not as scrutinised or required compared to conventional medicines. Therefore, it is imperative that dentists are aware of the potential anti-thrombotic properties of CMs and ensure they ask patients specifically about CM use when taking a medical and drug history.

\section{Summary}

This review provides a guide for commonly used drugs dentists need to consider that contribute to post-operative bleeding when assessing a patient's bleeding risk. A range of drugs are now in clinical use for prevention of coronary and vascular syndromes, including the traditional and novel anti-platelets, warfarin, heparin and DOACs. Some commonly prescribed antidepressants and regular use of NSAIDs also contribute to increased bleeding risk as well. The available scientific evidence is weak regarding complementary medicines 
and their association with enhanced bleeding, but dentists need to be aware that several can contribute to post-operative bleeding. This review highlights the importance of taking a thorough medical and drug history to capture all medications that may contribute to increased bleeding. After considering the drug, procedure and patient factors that influence postoperative bleeding, risk stratification can then be calculated according to recommendations from Therapeutic Guidelines Oral and Dental Version 3. ${ }^{1}$ Dentists should also be encouraged to report any cases of adverse effects, including post-operative bleeding, to the Therapeutic Goods Administration in association with any drugs, including complementary medicines.

\section{Acknowledgements}

This research was supported by the Australian Government Research Training Program Scholarship (no. 241616). The authors report no conflict of interest.

\section{References}

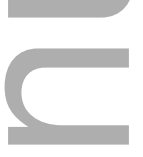

1. Oral and Dental Expert Group. Therapeutic Guidelines: Oral and Dental Version 3. Melbourne, Australia: Therapeutic Guidelines Ltd; 2019.

2. Clinical Excellence Commission. Guidelines on Perioperative Management of Anticoagulant and Antiplatelet Agents. 2018.

3. Scottish Dental Clinical Effectiveness Program. Management of Dental Patients taking Anticoagulants or Antiplatelet Drugs. Dundee, Scotland2015.

4. Rang HP, Dale MM, Ritter JM. Pharmacology. 4th ed. Edinburgh ; New York: Churchill Livingstone; 1999. x, 830 p. p.

5. Dave HD, LaPelusa A. Physiology, Hemostasis. StatPearls. Treasure Island (FL)2019.

6. Toschi V, Lettino M. Inhibitors of propagation of coagulation: factors $\mathrm{V}$ and $\mathrm{X}$. Br J Clin Pharmacol. 2011;72(4):563-580.

7. Thean $D$, Alberghini M. Anticoagulant therapy and its impact on dental patients: a review. Aust Dent J. 2016;61(2):149-156.

8. Wallentin L. P2Y(12) inhibitors: differences in properties and mechanisms of action and potential consequences for clinical use. Eur Heart J. 2009;30(16):1964-1977.

9. Expert Advisory Committee. Australian Medicines Handbook. 2019.

10. Pototski M, Amenabar JM. Dental management of patients receiving anticoagulation or antiplatelet treatment. J Oral Sci. 2007;49(4):253-258. 
11. Gaziano JM, Brotons C, Coppolecchia R, Cricelli C, Darius H, Gorelick PB, et al. Use of aspirin to reduce risk of initial vascular events in patients at moderate risk of cardiovascular disease (ARRIVE): a randomised, double-blind, placebo-controlled trial. Lancet. 2018;392(10152):1036-1046.

12. McNeil JJ, Nelson MR, Woods RL, Lockery JE, Wolfe R, Reid CM, et al. Effect of Aspirin on AllCause Mortality in the Healthy Elderly. N Engl J Med. 2018;379(16):1519-1528.

13. McNeil JJ, Wolfe R, Woods RL, Tonkin AM, Donnan GA, Nelson MR, et al. Effect of Aspirin on Cardiovascular Events and Bleeding in the Healthy Elderly. N Engl J Med. 2018;379(16):1509-1518.

14. McNeil JJ, Woods RL, Nelson MR, Reid CM, Kirpach B, Wolfe R, et al. Effect of Aspirin on Disability-free Survival in the Healthy Elderly. N Engl J Med. 2018;379(16):1499-1508.

15. Antithrombotic Trialists' Collaboration. Collaborative meta-analysis of randomised trials of antiplatelet therapy for prevention of death, myocardial infarction, and stroke in high risk patients. BMj. 2002(324):71-86.

16. Clopidogrel. 2019 URL: www.emims.com.au. Accessed 8 October 2019.

17. Asasantin SR, Dipyridamole, Aspirin. 2019 URL: www.emims.com.au. Accessed 8 October 2019.

18. Johnston S. An evidence summary of the management of the care of patients taking novel oral antiplatelet drugs undergoing dental surgery. Journal of the American Dental Association (1939). 2016;147(4):271-277.

19. Ticagrelor. 2019 URL: www.emims.com.au. Accessed 8 October 2019.

20. Husted S, Emanuelsson H, Heptinstall S, Sandset PM, Wickens M, Peters G.

Pharmacodynamics, pharmacokinetics, and safety of the oral reversible P2Y12 antagonist AZD6140 with aspirin in patients with atherosclerosis: a double-blind comparison to clopidogrel with aspirin. Eur Heart J. 2006;27(9):1038-1047.

21. Wallentin L, Becker RC, Budaj A, Cannon CP, Emanuelsson H, Held C, et al. Ticagrelor versus clopidogrel in patients with acute coronary syndromes. N Engl J Med. 2009;361(11):1045-1057.

22. Heparin Sodium. 2019 URL: www.emims.com.au. Accessed 8 October 2019.

23. Salam S, Yusuf H, Milosevic A. Bleeding after dental extractions in patients taking warfarin. Br J Oral Maxillofac Surg. 2007;45(6):463-466.

24. Australian Government Department of Health. PBS and RPBS Section 85 Date of Processing and Date of Supply Data 2017. URL: http://www.pbs.gov.au/info/statistics/dos-and-dop/dos-anddop. Accessed 1 August 2019.

25. Lanau N, Mareque J, Giner L, Zabalza M. Direct oral anticoagulants and its implications in dentistry. A review of literature. J Clin Exp Dent. 2017;9(11):e1346-e1354.

This article is protected by copyright. All rights reserved 
26. Johnston S. An evidence summary of the management of patients taking direct oral anticoagulants (DOACs) undergoing dental surgery. Int J Oral Maxillofac Surg. 2016;45(5):618-630.

27. Dabigatran. 2019 URL: www.emims.com.au. Accessed 8 October 2019.

28. Fortier K, Shroff D, Reebye UN. Review: An overview and analysis of novel oral anticoagulants and their dental implications. Gerodontology. 2018;35(2):78-86.

29. Rivaroxaban. 2019. URL: www.emims.com.au. Accessed 8 October 2019.

30. Apixaban. 2019. URL: www.emims.com.au. Accessed 8 October 2019.

31. Wahl MJ. Dental surgery and antiplatelet agents: bleed or die. Am J Med. 2014;127(4):260-

267.

32. Sambrook P. Dentistry concerns for patients taking anticoagulants and antiplatelet drugs. Aust Prescr. 2018;41(4):116.

33. Bensi C, Belli S, Paradiso D, Lomurno G. Postoperative bleeding risk of direct oral anticoagulants after oral surgery procedures: a systematic review and meta-analysis. Int J Oral Maxillofac Surg. 2018;47(7):923-932.

34. Mauprivez C, Khonsari RH, Razouk O, Goudot P, Lesclous P, Descroix V. Management of dental extraction in patients undergoing anticoagulant oral direct treatment: a pilot study. Oral Surg Oral Med Oral Pathol Oral Radiol. 2016;122(5):e146-e55.

35. Doganay O, Atalay B, Karadag E, Aga U, Tugrul M. Bleeding frequency of patients taking ticagrelor, aspirin, clopidogrel, and dual antiplatelet therapy after tooth extraction and minor oral surgery. Journal of the American Dental Association (1939). 2018;149(2):132-138.

36. Olmos-Carrasco O, Pastor-Ramos V, Espinilla-Blanco R, Ortiz-Zarate A, Garcia-Avila I, Rodriguez-Alonso $\mathrm{E}$, et al. Hemorrhagic complications of dental extractions in 181 patients undergoing double antiplatelet therapy. J Oral Maxillofac Surg. 2015;73(2):203-210.

37. Kelley BP, Bennett KG, Chung KC, Kozlow JH. Ibuprofen May Not Increase Bleeding Risk in Plastic Surgery: A Systematic Review and Meta-Analysis. Plast Reconstr Surg. 2016;137(4):13091316.

38. Napenas JJ, Hong CH, Kempter E, Brennan MT, Furney SL, Lockhart PB. Selective serotonin reuptake inhibitors and oral bleeding complications after invasive dental treatment. Oral Surg Oral Med Oral Pathol Oral Radiol Endod. 2011;112(4):463-467.

39. Shin $\mathrm{D}, \mathrm{Oh} \mathrm{YH}$, Eom CS, Park SM. Use of selective serotonin reuptake inhibitors and risk of stroke: a systematic review and meta-analysis. J Neurol. 2014;261(4):686-695.

40. Dalton SO, Johansen C, Mellemkjaer L, Norgard B, Sorensen HT, Olsen JH. Use of selective serotonin reuptake inhibitors and risk of upper gastrointestinal tract bleeding: a population-based cohort study. Arch Intern Med. 2003;163(1):59-64.

This article is protected by copyright. All rights reserved 
41. de Abajo FJ, Rodriguez LA, Montero D. Association between selective serotonin reuptake inhibitors and upper gastrointestinal bleeding: population based case-control study. BMJ. 1999;319(7217):1106-1109.

42. Sarma A, Horne MK, 3rd. Venlafaxine-induced ecchymoses and impaired platelet aggregation. Eur J Haematol. 2006;77(6):533-537.

43. de Abajo FJ, Garcia-Rodriguez LA. Risk of upper gastrointestinal tract bleeding associated with selective serotonin reuptake inhibitors and venlafaxine therapy: interaction with nonsteroidal anti-inflammatory drugs and effect of acid-suppressing agents. Arch Gen Psychiatry. 2008;65(7):795803.

44. Jiang HY, Chen HZ, Hu XJ, Yu ZH, Yang W, Deng M, et al. Use of selective serotonin reuptake inhibitors and risk of upper gastrointestinal bleeding: a systematic review and meta-analysis. Clin Gastroenterol Hepatol. 2015;13(1):42-50.

45. Anglin R, Yuan Y, Moayyedi P, Tse F, Armstrong D, Leontiadis Gl. Risk of upper gastrointestinal bleeding with selective serotonin reuptake inhibitors with or without concurrent nonsteroidal anti-inflammatory use: a systematic review and meta-analysis. Am J Gastroenterol. 2014;109(6):811-819.

46. Weinrieb RM, Auriacombe M, Lynch KG, Lewis JD. Selective serotonin re-uptake inhibitors and the risk of bleeding. Expert Opin Drug Saf. 2005;4(2):337-344.

47. Leong C, Alessi-Severini S, Enns MW, Nie Y, Sareen J, Bolton J, et al. Cerebrovascular, Cardiovascular, and Mortality Events in New Users of Selective Serotonin Reuptake Inhibitors and Serotonin Norepinephrine Reuptake Inhibitors: A Propensity Score-Matched Population-Based Study. J Clin Psychopharmacol. 2017;37(3):332-340.

48. Laporte S, Chapelle C, Caillet P, Beyens MN, Bellet F, Delavenne X, et al. Bleeding risk under selective serotonin reuptake inhibitor (SSRI) antidepressants: A meta-analysis of observational studies. Pharmacol Res. 2017;118:19-32.

49. Therapeutic Goods Administration Department of Health. An overview of the regulation of complementary medicines in Australia. URL: https://www.tga.gov.au/overview-regulationcomplementary-medicines-australia. Accessed 30 October 2019.

50. von Conrady DM, Bonney A. Patterns of complementary and alternative medicine use and health literacy in general practice patients in urban and regional Australia. Aust Fam Physician. 2017;46(5):316-320.

51. Reid R, Steel A, Wardle J, Trubody A, Adams J. Complementary medicine use by the Australian population: a critical mixed studies systematic review of utilisation, perceptions and factors associated with use. BMC Complement Altern Med. 2016;16:176. 
52. Abebe W. Review of herbal medications with the potential to cause bleeding: dental implications, and risk prediction and prevention avenues. EPMA J. 2019;10(1):51-64.

53. Eisenberg DM, Davis RB, Ettner SL, Appel S, Wilkey S, Van Rompay M, et al. Trends in alternative medicine use in the United States, 1990-1997: results of a follow-up national survey. JAMA. 1998;280(18):1569-1575.

54. Abebe W. Herbal medication: potential for adverse interactions with analgesic drugs. J Clin Pharm Ther. 2002;27(6):391-401.

55. Segal R, Pilote L. Warfarin interaction with Matricaria chamomilla. CMAJ. 2006;174(9):12811282.

56. Page RL, 2nd, Lawrence JD. Potentiation of warfarin by dong quai. Pharmacotherapy. 1999;19(7):870-876.

57. Yin ZZ, Zhang LY, Xu LN. [The effect of Dang-Gui (Angelica sinensis) and its ingredient ferulic acid on rat platelet aggregation and release of 5-HT (author's transl)]. Yao Xue Xue Bao. 1980;15(6):321-326.

58. Natural Medicines Database. URL: https://naturalmedicines.therapeuticresearch.com/. Accessed 20 December 2019.

59. De La Cruz JP, Martin-Romero M, Carmona JA, Villalobos MA, Sanchez de la Cuesta F. Effect of evening primrose oil on platelet aggregation in rabbits fed an atherogenic diet. Thromb Res. 1997;87(1):141-149.

60. Yang C, Li L, Yang L, Lu H, Wang S, Sun G. Anti-obesity and Hypolipidemic effects of garlic oil and onion oil in rats fed a high-fat diet. Nutr Metab (Lond). 2018;15:43.

61. Bordia A. Effect of garlic on human platelet aggregation in vitro. Atherosclerosis. 1978;30(4):355-360.

62. Abebe W. Herbal supplements having the potential to interfere with blood clotting. GDA Action. 2003;22:23-24.

63. Shankland WE, 2nd. Four common herbs seen in dental practice: properties and potential adverse effects. Cranio. 2009;27(2):118-124.

64. Ge B, Zhang Z, Zuo Z. Updates on the clinical evidenced herb-warfarin interactions. Evid Based Complement Alternat Med. 2014:957362.

65. Srivastava KC. Aqueous extracts of onion, garlic and ginger inhibit platelet aggregation and alter arachidonic acid metabolism. Biomed Biochim Acta. 1984;43(8-9):S335-346.

66. Chung KF, Dent G, McCusker M, Guinot P, Page CP, Barnes PJ. Effect of a ginkgolide mixture (BN 52063) in antagonising skin and platelet responses to platelet activating factor in man. Lancet. 1987;1(8527):248-251. 
67. Rosenblatt M, Mindel J. Spontaneous hyphema associated with ingestion of Ginkgo biloba extract. N Engl J Med. 1997;336(15):1108.

68. Kuo SC, Teng CM, Lee JC, Ko FN, Chen SC, Wu TS. Antiplatelet components in Panax ginseng. Planta Med. 1990;56(2):164-167.

69. Park HJ, Lee JH, Song YB, Park KH. Effects of dietary supplementation of lipophilic fraction from Panax ginseng on cGMP and cAMP in rat platelets and on blood coagulation. Biol Pharm Bull. 1996;19(11):1434-1439.

70. Miller LG. Herbal medicinals: selected clinical considerations focusing on known or potential drug-herb interactions. Arch Intern Med. 1998;158(20):2200-2211.

71. Lin PC, Jones SO, McGlasson DL. Effects of glucosamine and Celadrin on platelet function. Clin Lab Sci. 2010;23(1):32-36.

72. Srivastava KC, Bordia A, Verma SK. Curcumin, a major component of food spice turmeric (Curcuma longa) inhibits aggregation and alters eicosanoid metabolism in human blood platelets. Prostaglandins Leukot Essent Fatty Acids. 1995;52(4):223-227.

73. Jantan I, Raweh SM, Sirat HM, Jamil S, Mohd Yasin YH, Jalil J, et al. Inhibitory effect of compounds from Zingiberaceae species on human platelet aggregation. Phytomedicine. 2008;15(4):306-309.

74. Prakash P, Misra A, Surin WR, Jain M, Bhatta RS, Pal R, et al. Anti-platelet effects of Curcuma oil in experimental models of myocardial ischemia-reperfusion and thrombosis. Thromb Res. 2011;127(2):111-118.

75. Memorial Sloan Kettering Cancer Center. URL: https://www.mskcc.org/cancercare/integrative-medicine/herbs/turmeric. Accessed 20 December 2019.

76. Psychotropic Guidelines Expert Group. Therapeutic Guidelines Psychotropic Version 7. Therapeutic Guidelines Pty Ltd, Melbourne Australia. 2013.

\section{Figure Legend}

Figure 1. Coagulation cascade (reproduced from Fortier et $\mathrm{al}^{28}$ ) 
Table 1. Pharmacological properties of anti-platelet drugs

\begin{tabular}{|c|c|c|c|c|}
\hline Generic name & $\begin{array}{l}\text { Some commercial } \\
\text { names }\end{array}$ & Onset and maximum effect & Degree of IPA* & When to stop before surgery ${ }^{1,2,9} \wedge$ \\
\hline $\begin{array}{l}\text { Aspirin (75- } \\
150 \mathrm{mg} / \text { day) }\end{array}$ & $\begin{array}{l}\text { Spren } \\
\text { Cardiprin } \\
\text { Cartia } \\
\text { Astrix }\end{array}$ & Maximum effect: $30-60$ minutes & Unknown & $\begin{array}{l}\text { - Unlikely or low bleeding risk: do not stop } \\
\text { - High risk of bleeding: undertake protocol from } \\
\text { TGO\&D } 3^{1}\end{array}$ \\
\hline Dipyridamole & $\begin{array}{l}\text { Persantin } \\
\text { Asasantin SR } \\
\text { (Aspirin/dipyridamole) }\end{array}$ & & Unknown & $\begin{array}{l}\text { Single antiplatelet therapy: } \\
\text { - } \quad \text { Unlikely or low bleeding risk: do not stop } \\
\text { - } \quad \text { High risk of bleeding: undertake protocol from } \\
\text { TGO\&D3 }{ }^{1} \\
\text { Dual antiplatelet therapy: } \\
\text { - } \quad \text { Unlikely bleeding risk: do not stop } \\
\text { - Low bleeding risk without patient-related bleeding risk } \\
\text { - } \quad \text { Lactors: do not stop } \\
\text { factors or high bleeding risk: undertake protocol from } \\
\text { TGO\&D }{ }^{1}\end{array}$ \\
\hline Clopidogrel & $\begin{array}{l}\text { Clovix } \\
\text { Iscover } \\
\text { Piax } \\
\text { Plavix } \\
\text { CoPlavix } \\
\text { (Aspirin/Clopidogrel) }\end{array}$ & $\begin{array}{l}\text { Onset } 1-2 \text { hours } \\
\text { Time to maximum effect depends on } \\
\text { dose: } 2-3 \text { hours after } 600 \mathrm{mg} \text {; } 4-5 \text { hours } \\
\text { after } 300 \mathrm{mg} \text {; } 7 \text { days after } 75 \mathrm{mg}\end{array}$ & $50 \%{ }^{8,16}$ & $\begin{array}{l}\text { Single antiplatelet therapy: } \\
\text { - Unlikely or low bleeding risk: do not stop } \\
\text { - High risk of bleeding: undertake protocol from } \\
\text { TGO\&D3 }{ }^{1} \\
\text { Dual antiplatelet therapy: } \\
\text { - Unlikely bleeding risk: do not stop } \\
\text { - } \quad \text { Low bleeding risk without patient-related bleeding risk }\end{array}$ \\
\hline
\end{tabular}

This article is protected by copyright. All rights reserved 


\begin{tabular}{|c|c|c|c|c|}
\hline & ני & & & $\begin{array}{l}\text { factors: do not stop } \\
\text { - Low bleeding risk with patient-related bleeding risk } \\
\text { factors or high bleeding risk: undertake protocol from } \\
\text { TGO\&D3 }{ }^{1}\end{array}$ \\
\hline Prasugrel & Effient & $\begin{array}{l}\text { After loading dose: } \\
\text { Onset } 15-30 \text { minutes } \\
\text { Maximum effect: } 2-4 \text { hours }\end{array}$ & $70 \%{ }^{8}$ & $\begin{array}{l}\text { - Unlikely or low bleeding risk: do not stop } \\
\text { - High risk of bleeding: undertake protocol from } \\
\text { TGO\&D3 }{ }^{1}\end{array}$ \\
\hline Ticagrelor & Brilinta & $\begin{array}{l}\text { After loading dose: } \\
\text { Onset: } 30 \text { minutes } \\
\text { Maximum effect: } 2-4 \text { hours }\end{array}$ & $90 \%{ }^{19}$ & $\begin{array}{l}\text { - Unlikely or low bleeding risk: do not stop } \\
\text { - High risk of bleeding: undertake protocol from } \\
\text { TGO\&D3 }{ }^{1}\end{array}$ \\
\hline
\end{tabular}

*IPA: Inhibition of platelet aggregation

^Anti-platelet medication should not be stopped without a risk assessment undertaken with the prescribing medical doctor. Unlikely, low and high bleeding risk refer to procedural classifications. Procedural classifications and patient bleeding risk factors are both defined as outlined in Therapeutic Guidelines Oral and Dental Version 3. Advice applies to single antiplatelet therapy unless otherwise stated and not including any other anti-thrombotic medicines. Overall bleeding risk assessment depends on patient-, procedure-factors and all drugs that contribute to bleeding risk.

Consider specialist referral for procedures with a higher risk of prolonged bleeding in patients taking anti-thrombotic drugs.

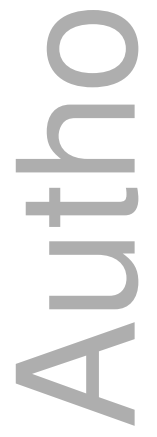

This article is protected by copyright. All rights reserved 
Table 2. Pharmacological properties of anti-coagulants

\begin{tabular}{|c|c|c|c|c|c|c|}
\hline $\begin{array}{l}\text { Generic } \\
\text { name }\end{array}$ & $\begin{array}{l}\text { Commercial } \\
\text { name }^{9}\end{array}$ & $\begin{array}{l}\text { Mechanism of } \\
\text { action }\end{array}$ & $\begin{array}{l}\text { Monitoring of } \\
\text { anticoagulation }\end{array}$ & Onset of action ${ }^{9}$ & When to stop before surgery ${ }^{1 \wedge}$ & Antidote \\
\hline Warfarin & $\begin{array}{l}\text { Coumadin } \\
\text { Marevan }\end{array}$ & $\begin{array}{l}\text { Vitamin K } \\
\text { antagonist }\end{array}$ & $\begin{array}{l}\text { International } \\
\text { normalised ratio }\end{array}$ & 36-72 hours & 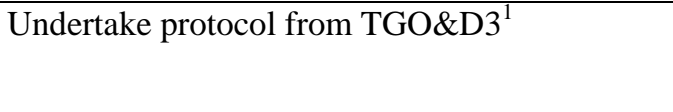 & Phytonadione (Vitamin K) \\
\hline Heparin & $\begin{array}{l}\text { Heparin } \\
\text { Sodium }\end{array}$ & $\begin{array}{l}\text { Enhances } \\
\text { antithrombin III }\end{array}$ & $\begin{array}{l}\text { Activated partial } \\
\text { thromboplastin } \\
\text { time }\end{array}$ & $\begin{array}{l}\text { IV onset: immediate } \\
\text { Subcutaneous onset: } 20 \text { - } \\
60 \text { minutes }\end{array}$ & $\begin{array}{l}\text { Often used as bridging therapy during surgery, } \\
\text { consult physician }\end{array}$ & Protamine \\
\hline Dalteparin & Fragmin & $\begin{array}{l}\text { Low molecular } \\
\text { weight heparin - } \\
\text { inhibits Factor Xa }\end{array}$ & $\begin{array}{l}\text { Antifactor Xa } \\
\text { levels }\end{array}$ & 3 hours & Consult physician & Protamine \\
\hline Enoxaparin & Clexane & $\begin{array}{l}\text { Low molecular } \\
\text { weight heparin - } \\
\text { inhibits Factor Xa }\end{array}$ & $\begin{array}{l}\text { Antifactor Xa } \\
\text { levels }\end{array}$ & 3 hours & Consult physician & Protamine \\
\hline Dabigatran & Pradaxa & $\begin{array}{l}\text { Direct thrombin } \\
\text { inhibitor }\end{array}$ & - & 30 minutes & $\begin{array}{l}\text { - } \\
\text { - } \\
\text { Lowlikely bleeding risk: do not stop } \\
\text { bleeding risk factors: do not stop } \\
\text { - Low bleeding risk with patient-related } \\
\text { bleeding risk factors or high bleeding risk: } \\
\text { undertake protocol from TGO\&D }{ }^{1}\end{array}$ & Idaricuzumab \\
\hline Rivaroxaban & Xarelto & $\begin{array}{l}\text { Factor Xa } \\
\text { inhibitor }\end{array}$ & - & 30 minutes & $\begin{array}{l}\text { - Unlikely bleeding risk: do not stop } \\
\text { - Low bleeding risk without patient-related } \\
\text { bleeding risk factors: do not stop } \\
\text { - } \quad \text { Low bleeding risk with patient-related } \\
\text { bleeding risk factors or high bleeding risk: } \\
\text { undertake protocol from TGO\&D }{ }^{1}\end{array}$ & Andexanet alfa* \\
\hline Apixaban & Eliquis & Factor $\mathrm{Xa}$ & - & 30 minutes & - Unlikely bleeding risk: do not stop & Andexanet alfa* \\
\hline
\end{tabular}

This article is protected by copyright. All rights reserved 


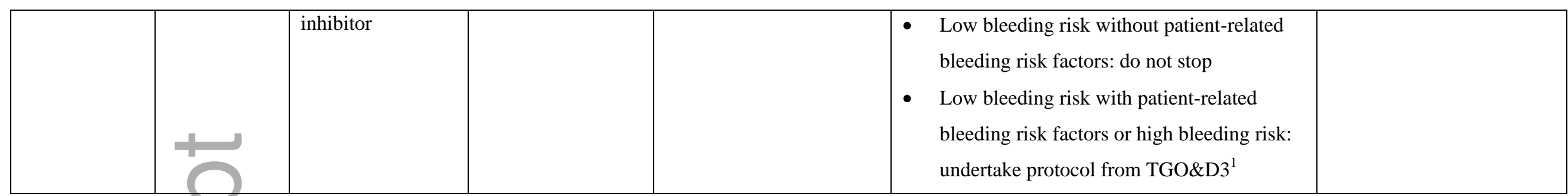

*Not yet approved for use in Australia

$\wedge$ Anti-coagulant medication should not be stopped without a risk assessment undertaken with the prescribing medical doctor. Unlikely, low and high bleeding risk refer to procedural classifications. Procedural classifications and patient bleeding risk factors are outlined in Therapeutic Guidelines Oral and Dental Version 3. Advice applies to single oral anticoagulant therapy unless otherwise stated and not including any other anti-thrombotic medicines. Overall bleeding risk assessment depends on patient-, procedure-factors and all drugs that contribute to bleeding risk.

Consider specialist referral for procedures with a higher risk of prolonged bleeding in patients taking antithrombotic drugs.

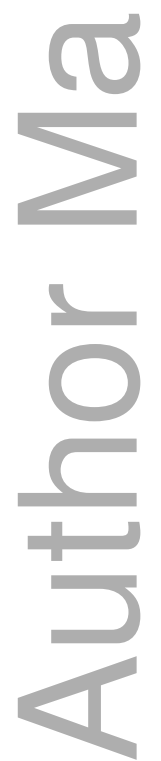

This article is protected by copyright. All rights reserved 
Table 3. Common uses and brand names of anti-depressants that contribute to bleeding risk ${ }^{9}$

\begin{tabular}{|c|c|c|c|c|}
\hline Generic name & $\begin{array}{l}\text { Some commercial } \\
\text { names }\end{array}$ & Drug class & Registered uses & When to stop before surgery \\
\hline Citalopram & $\begin{array}{l}\text { Cipramil } \\
\text { Citalo } \\
\text { Celapram }\end{array}$ & $\begin{array}{l}\text { Selective serotonin } \\
\text { re-uptake inhibitor }\end{array}$ & Major depression & \multirow{5}{*}{$\begin{array}{l}\text { Antidepressants are rarely ceased prior to } \\
\text { surgery due to high risk of withdrawal } \\
\text { syndrome. } \\
\text { If an anti-depressant is no longer clinically } \\
\text { necessary and requires cessation, withdrawal } \\
\text { should only be conducted under close } \\
\text { medical supervision with gradual dose } \\
\text { tapering over } 2-4 \text { weeks as outlined in } \\
\text { Therapeutic Guidelines Psychotropic. }^{76}\end{array}$} \\
\hline Escitalopram & $\begin{array}{l}\text { Lexapro } \\
\text { Esipram } \\
\text { Escicor }\end{array}$ & $\begin{array}{l}\text { Selective serotonin } \\
\text { re-uptake inhibitor }\end{array}$ & $\begin{array}{l}\text { Major depression } \\
\text { Generalised anxiety disorder } \\
\text { Social phobia } \\
\text { Obsessive-compulsive disorder }\end{array}$ & \\
\hline Fluoxetine & $\begin{array}{l}\text { Lovan } \\
\text { Prozac } \\
\text { Auscap } \\
\text { Zactin }\end{array}$ & $\begin{array}{l}\text { Selective serotonin } \\
\text { re-uptake inhibitor }\end{array}$ & $\begin{array}{l}\text { Major depression } \\
\text { Obsessive-compulsive disorder } \\
\text { Premenstrual dysphoric disorder }\end{array}$ & \\
\hline Fluvoxamine & $\begin{array}{l}\text { Faverin } \\
\text { Luvox } \\
\text { Movox } \\
\text { Voxam }\end{array}$ & $\begin{array}{l}\text { Selective serotonin } \\
\text { re-uptake inhibitor }\end{array}$ & $\begin{array}{l}\text { Major depression } \\
\text { Obsessive-compulsive disorder }\end{array}$ & \\
\hline Paroxetine & $\begin{array}{l}\text { Aropax } \\
\text { Extine } \\
\text { Paxtine }\end{array}$ & $\begin{array}{l}\text { Selective serotonin } \\
\text { re-uptake inhibitor }\end{array}$ & $\begin{array}{l}\text { Major depression } \\
\text { Obsessive-compulsive disorder } \\
\text { Panic disorder } \\
\text { Generalised anxiety disorder } \\
\text { Post-traumatic stress disorder }\end{array}$ & \\
\hline
\end{tabular}

This article is protected by copyright. All rights reserved 


\begin{tabular}{|c|c|c|c|c|}
\hline & & & Social phobia & \\
\hline Sertraline & $\begin{array}{l}\text { Sertra } \\
\text { Eleva } \\
\text { Xydep } \\
\text { Zoloft }\end{array}$ & $\begin{array}{l}\text { Selective serotonin } \\
\text { re-uptake inhibitor }\end{array}$ & $\begin{array}{l}\text { Major depression } \\
\text { Obsessive-compulsive disorder } \\
\text { Panic disorder } \\
\text { Social phobia } \\
\text { Premenstrual dysphoric disorder }\end{array}$ & \\
\hline Venlafaxine & $\begin{array}{l}\text { Efexor } \\
\text { Efexor-XR } \\
\end{array}$ & $\begin{array}{l}\text { Serotonin and } \\
\text { noradrenaline re- } \\
\text { uptake inhibitor }\end{array}$ & $\begin{array}{l}\text { Major depression } \\
\text { Generalised anxiety disorder } \\
\text { Panic disorder } \\
\text { Social phobia }\end{array}$ & \\
\hline
\end{tabular}

This article is protected by copyright. All rights reserved 
Table 4. Selected herbal supplements with potential to increase bleeding risk. (adapted from Abebe ${ }^{52}$ )

\begin{tabular}{|c|c|c|c|}
\hline $\begin{array}{l}\text { Herbal } \\
\text { supplements }\end{array}$ & Effects on blood clotting & $\begin{array}{l}\text { Potential interactions with anti-thrombotic } \\
\text { medications }\end{array}$ & Time to cease before surgery \\
\hline Dong quai & $\begin{array}{l}\text { Coumarins and ferulic acid have anticoagulant } \\
\text { and antiplatelet effects respectively; ferulic acid } \\
\text { increases bleeding by inhibiting release of } \\
\text { serotonin and ADP. }\end{array}$ & $\begin{array}{l}\text { Increased risk of bleeding with warfarin, and } \\
\text { also possibly with aspirin and other NSAIDs }\end{array}$ & \multirow{6}{*}{$\begin{array}{l}\text { All complementary medicines that are } \\
\text { not clinically necessary and increase risk } \\
\text { of bleeding should be ceased wherever } \\
\text { possible prior to surgery. Duration } \\
\text { required is } 10-14 \text { days, to allow time for } \\
\text { platelet function to be restored. }^{58}\end{array}$} \\
\hline $\begin{array}{l}\text { Evening } \\
\text { primrose }\end{array}$ & $\begin{array}{l}\text { Constituents associated with reduction of TXA2, } \\
\text { decreased platelet aggregation, and increased } \\
\text { bleeding time }\end{array}$ & $\begin{array}{l}\text { Increased risk of bleeding with aspirin, } \\
\text { warfarin and some NSAIDs }\end{array}$ & \\
\hline Fish Oil & $\begin{array}{l}\text { Associated with reduction of TXA2, decreased } \\
\text { platelet aggregation, and increased bleeding } \\
\text { time. }^{58}\end{array}$ & Doses $3 \mathrm{~g}$ or higher have antiplatelet effect. ${ }^{58}$ & \\
\hline Garlic & $\begin{array}{l}\text { Certain constituents inhibit platelet aggregation } \\
\text { and induce bleeding under different conditions by } \\
\text { inhibiting production/release of various mediators } \\
\text { including TXA2, ADP, PAF and adenosine. }\end{array}$ & $\begin{array}{l}\text { Augments the anti-thrombotic effects of } \\
\text { aspirin, NSAIDs and warfarin. }\end{array}$ & \\
\hline Ginger & $\begin{array}{l}\text { Certain constituents reduce platelet aggregation } \\
\text { by inhibiting synthesis of TXA2, with the } \\
\text { potential to increase bleeding risk }\end{array}$ & Increased bleeding reported with warfarin. & \\
\hline Ginkgo & $\begin{array}{l}\text { Certain components, particularly ginkgolides, } \\
\text { inhibit platelet aggregation and cause bleeding by }\end{array}$ & $\begin{array}{l}\text { Increased bleeding risk reported with anti- } \\
\text { platelet drugs and warfarin. }\end{array}$ & \\
\hline
\end{tabular}

This article is protected by copyright. All rights reserved 


\begin{tabular}{|c|c|c|c|}
\hline & inhibiting PAF formation & & \\
\hline Ginseng & $\begin{array}{l}\text { Some components have antiplatelet effects with } \\
\text { the risk of causing increased bleeding via } \\
\text { inhibition of TXA2 }\end{array}$ & $\begin{array}{l}\text { No reports of interactions with antiplatelet } \\
\text { medications, potential interaction with } \\
\text { warfarin }\end{array}$ & \\
\hline Glucosamine & $\begin{array}{l}\text { Glucosamine is associated with inhibition of } \\
\text { platelet function by inhibition of the ADP } \\
\text { receptor, P2Y1. }\end{array}$ & $\begin{array}{l}\text { Several case reports associate glucosamine } \\
\text { alone with an increased INR with patients } \\
\text { who are taking warfarin. }\end{array}$ & \\
\hline Turmeric & $\begin{array}{l}\text { Curcuminoids inhibit platelet aggregation by } \\
\text { inhibiting arachidonic acid metabolism and } \\
\text { TXA2 synthesis }\end{array}$ & $\begin{array}{l}\text { Curcuminoids can inhibit CYP3A4 which } \\
\text { metabolises all oral anticoagulants to some } \\
\text { extent, and may block p-glycoprotein } \\
\text { transport. Outcome is increased serum levels } \\
\text { of anticoagulants. }\end{array}$ & \\
\hline
\end{tabular}

This article is protected by copyright. All rights reserved 


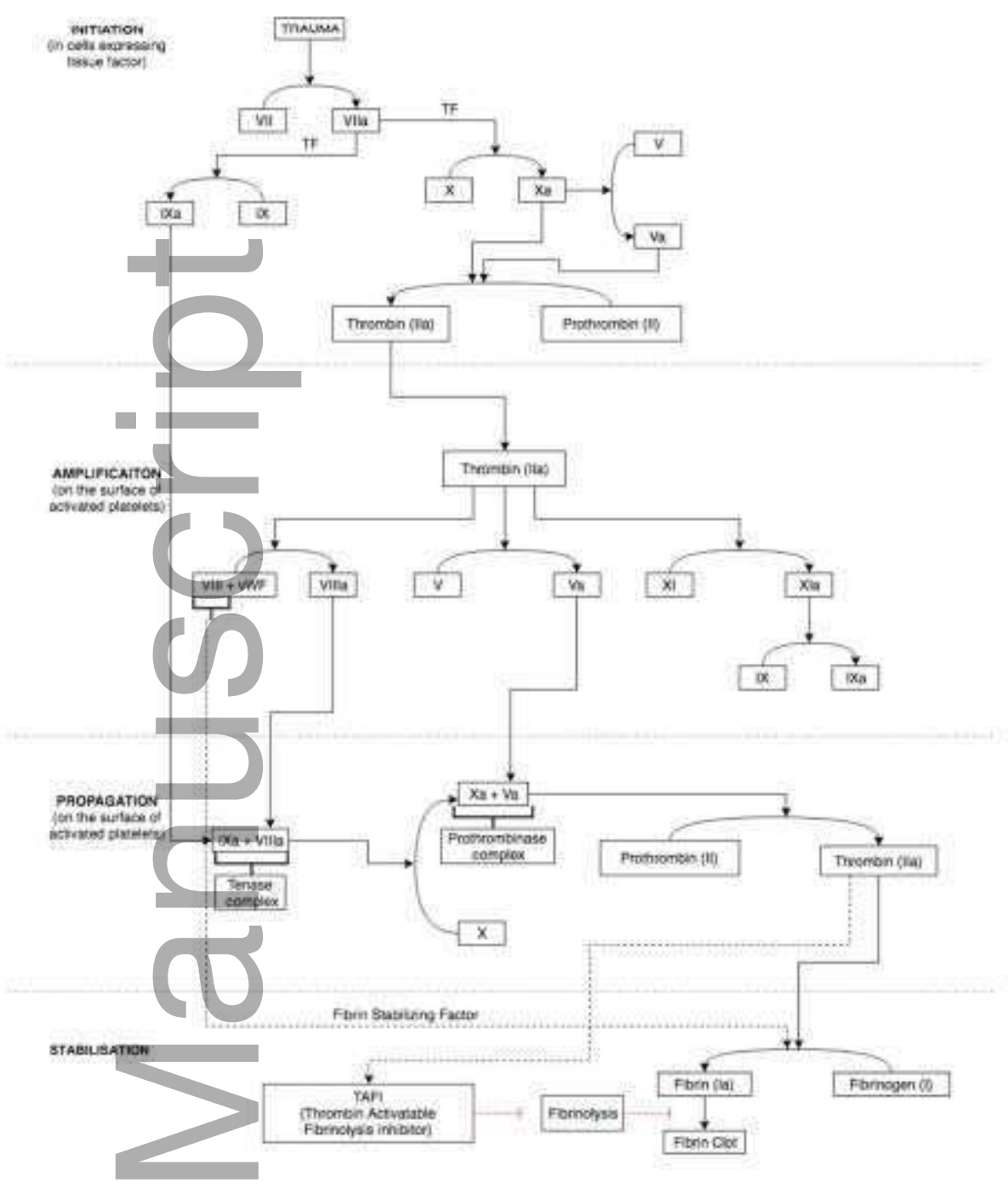

Figure 1. Coagulation cascade (reproduced from Fortier et $\mathrm{al}^{28}$ )

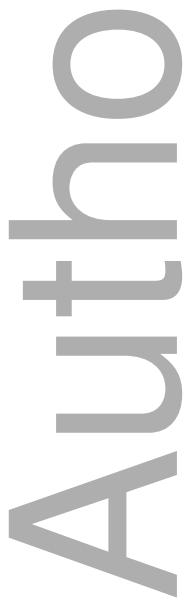

This article is protected by copyright. All rights reserved 


\section{University Library}

\section{- M M N E R VA A gateway to Melbourne's research publications}

Minerva Access is the Institutional Repository of The University of Melbourne

Author/s:

Teoh, L;Moses, G;McCullough, MJ

Title:

A review of drugs that contribute to bleeding risk in general dental practice

Date:

2020-06-01

Citation:

Teoh, L., Moses, G. \& McCullough, M. J. (2020). A review of drugs that contribute to bleeding risk in general dental practice. AUSTRALIAN DENTAL JOURNAL, 65 (2), pp.118-130. https://doi.org/10.1111/adj.12751.

Persistent Link:

http://hdl.handle.net/11343/275540 